\title{
Farmed bivalve loss due to seabream predation in the French Mediterranean Prevost Lagoon
}

\author{
Marion Richard ${ }^{1, *}$, Fabien Forget ${ }^{1}$, Alexandre Mignucci $^{1}{ }^{1}$, Serge Mortreux ${ }^{1}$, \\ Patrik Le Gall ${ }^{1}$, Myriam D. Callier ${ }^{2}$, Andrea M. Weise ${ }^{3}$, Christopher W. McKindsey ${ }^{3}$, \\ Jérôme Bourjea ${ }^{1}$
}

\author{
${ }^{1}$ MARBEC, Univ. Montpellier, CNRS, IRD, Ifremer, 34200 Sète, France \\ ${ }^{2}$ MARBEC, Univ. Montpellier, CNRS, IRD, Ifremer, 34250 Palavas, France \\ ${ }^{3}$ Fisheries and Oceans Canada, Maurice Lamontagne Institute, 850 route de la Mer, Mont-Joli, Quebec G5H 3Z4, Canada
}

\begin{abstract}
Bivalve predation by seabream has been observed worldwide and is a major concern for bivalve farmers. Farmed bivalve-seabream interactions must be better understood to ensure the sustainability of bivalve aquaculture. The objectives of this study were to characterize gilthead seabream Sparus aurata presence in a bivalve farm in Prevost Lagoon (Mediterranean Sea) using acoustic telemetry and to evaluate monthly losses of mussels Mytilus galloprovincialis and oysters Crassostrea gigas due to seabream predation over an 18 mo period inside the farm and at an unprotected experimental platform. Large ( 281 to $499 \mathrm{~mm}$ TL) seabream were more commonly detected in the bivalve farm than were small (200 to $280 \mathrm{~mm}$ TL) seabream. In contrast to small seabream, $90 \%$ of large seabream returned to and spent extended periods in the study area the following year, suggesting inter-annual site fidelity for large fish that used the bivalve farm as a feeding site. Signs of predation were observed on mussels and oysters throughout the year at the unprotected experimental platform. Farmers noted losses in the farm from April to September. Maximal losses (90 to $100 \%$ ) were observed post-oyster 'sticking' and mussel socking. Despite the deployment of nets as mechanical protection to reduce predation, oyster losses represented $28 \%$ of the annual value of oysters sold while mussel losses were estimated at ca. $1 \%$. These results suggest that bivalves must be protected by nets throughout the year to avoid predation, particularly post-handling. A collaboration between shellfish farmers and fishermen could be a sustainable solution for bivalve farming, by regularly fishing for seabream in farms, between tables and inside protective nets.
\end{abstract}

KEY WORDS: Shellfish culture - Sparus aurata - Size - Acoustic telemetry - Crassostrea gigas · Mytilus galloprovincialis $\cdot$ Oyster $\cdot$ Mussel

\section{INTRODUCTION}

Fisheries and aquaculture production from marine and coastal environments accounted for a global annual production of 171 million $t$ in 2016, of which 28.7 million $\mathrm{t}$ were from mariculture. Shelled mollusks accounted for $58.8 \%$ of marine and coastal aquaculture production (FAO 2018).

Bivalve farms create habitat that may act as a shelter, nursery, or feeding site for many species. Several

\footnotetext{
*Corresponding author: marion.richard@ifremer.fr
}

studies have shown that fish abundance (Brehmer et al. 2003), and notably seabream abundance (ŠegvićBubić et al. 2011, Sakai et al. 2013, Tsuyuki \& Umino 2017), may be greater within farm areas than in similar areas without farm activities. Predation by various species of seabream on farmed bivalves has been observed throughout the world, including Hiroshima Bay (Japan; Saito et al. 2008), the Ria de Ares-Betanzos (Spain; Peteiro et al. 2010), the Adriatic Sea (Croatia; Šegvić-Bubić et al. 2011), and the Mediterranean Sea

() M. Richard, F. Forget, A. Mignucci, S. Mortreux, P. Le Gall, M. D. Callier, J. Bourjea and Fisheries and Oceans Canada 2020. Open Access under Creative Commons by Attribution Licence. Use, distribution and reproduction are unrestricted. Authors and original publication must be credited.

Publisher: Inter-Research · www.int-res.com 
(France; Brehmer et al. 2003). Seabream have been shown to feed on farmed mussels and oysters (Saito et al. 2008, Šegvić-Bubić et al. 2011); however, little information is available on the magnitude of bivalve culture losses due to seabream predation.

In French Mediterranean lagoons, oysters Crassostrea gigas and mussels Mytilus galloprovincialis are reared on ropes suspended from metal structures, hereafter referred to as 'tables' (Gangnery et al. 2003). The main bivalve culture site on the French Mediterranean coast is Thau Lagoon, with a total annual production of ca. $10000 \mathrm{t}$ (oysters: $7327 \mathrm{t}$, mussels: 2117 t in 2016; Le Gal 2017). Bivalve losses due to gilthead seabream Sparus aurata predation is a major problem in the area. A survey of 135 farmers indicated that $93 \%$ of them were affected by seabream predation (Gervasoni \& Giffon 2016). To limit losses, $85 \%$ of surveyed bivalve farmers protect bivalves against seabream by deploying nets around the tables. However, this incurs significant financial and logistical costs, including purchasing nets, their deployment and maintenance, and potentially reduced bivalve growth due to reduced current flow and food delivery. Despite this physical protection, bivalve farmers have nonetheless estimated mean mussel losses due to seabream predation at $26 \%$ (Gervasoni \& Giffon 2016). Video recordings have shown that seabream may destroy mussel socking material, break shells, and eat mussels (Fig. 1). A shell- fish farm in nearby Prevost Lagoon with a smaller production of mussels and oysters (i.e. 12 tables vs. 2816 tables in Thau Lagoon) first reported massive losses due to seabream predation in 2016 following dredging work carried out in the farming area and lagoon entrance in 2015. Mussel losses were nearly $100 \%$, as bivalves were not protected by nets. Predation on juvenile oysters was also observed but losses were not estimated (bivalve farmers pers. comm.).

Gilthead seabream are opportunistic and adapt their diets to habitat and prey availability (Pita et al. 2002, Tancioni et al. 2003, Escalas et al. 2015). In the spring, from April to June, gilthead seabream enter coastal lagoons (Lasserre \& Labourg 1974, Mercier et al. 2012, Isnard et al. 2015) to feed (Tournois et al. 2013, Escalas et al. 2015, Isnard et al. 2015) and migrate seaward in the autumn when lagoon temperatures drop to those of the sea (Audouin 1962, Lasserre 1976). Passive acoustic telemetry has been successfully used to evaluate seabream movement and lagoon habitat use (Abecasis \& Erzini 2008), to describe the distribution and movements of escaped farmed fish from seacages (Arechavala-Lopez et al. 2012, 2018, Šegvić-Bubić et al. 2018), and to evaluate interactions with farm bivalve structures, as done for the black seabream Acanthopagrus schlegelii (Tsuyuki \& Umino 2017).

The objectives of the present study were to investigate gilthead seabream-farmed bivalve interactions

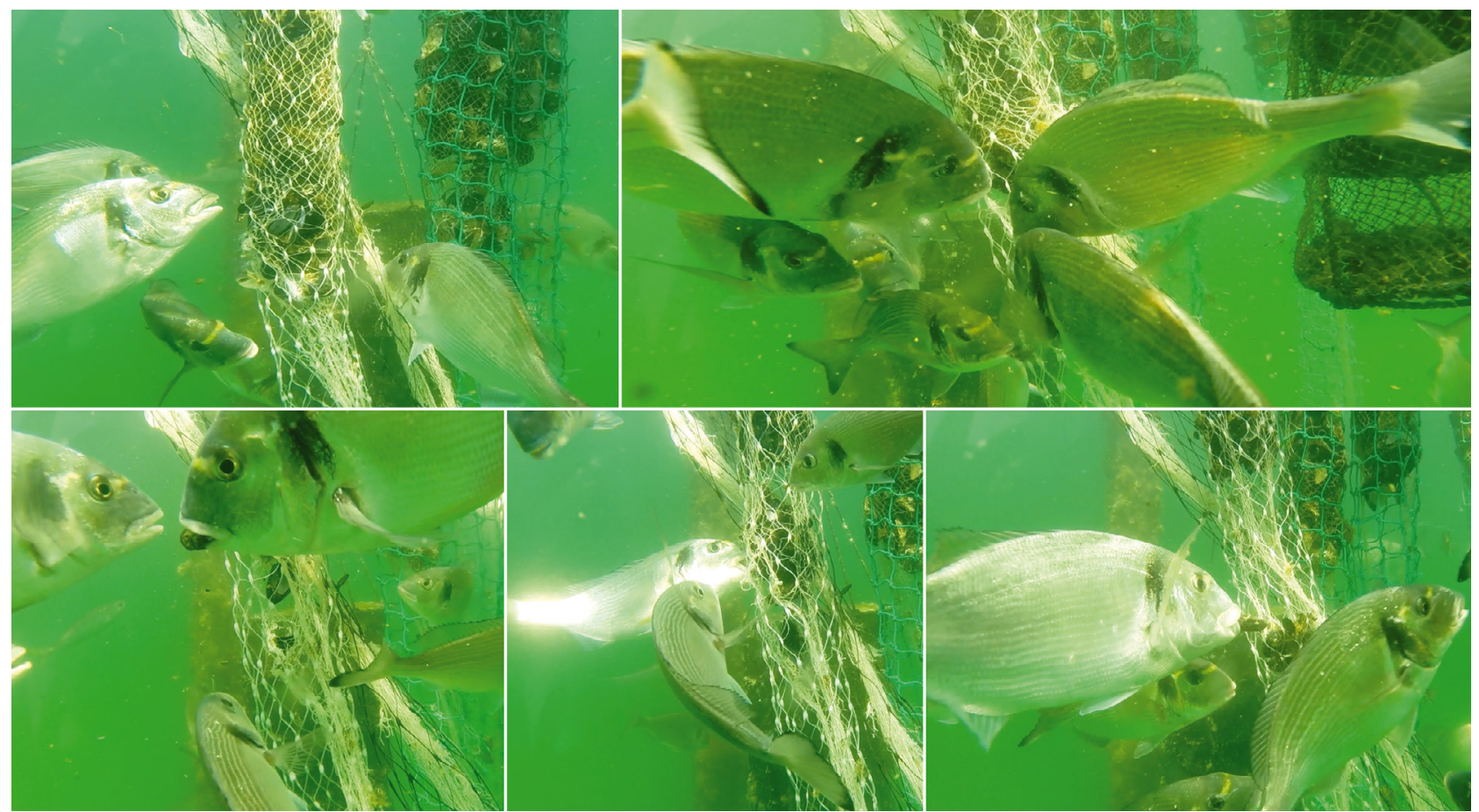

Fig. 1. Seabream Sparus aurata feeding on mussel ropes in Thau Lagoon, recorded with a GoPro Hero 4 camera 
and to evaluate farmed bivalve losses due to seabream predation. To this end, we describe the temporal variability of (1) seabream presence at the Prevost Lagoon bivalve farm using acoustic telemetry and (2) bivalve losses due to predation over 18 mo (April 2017 to October 2018).

\section{MATERIALS AND METHODS}

\subsection{Site and bivalve farm}

Prevost Lagoon is located in southern France (4331' $\left.13.70^{\prime \prime} \mathrm{N}, 3^{\circ} 54^{\prime} 33.31^{\prime \prime} \mathrm{E}\right)$, surrounded by the Pierre Blanche, Arnel, and Mejean lagoons and connected to the Rhone-Sete channel and to the Mediterranean Sea by the (locally called) 'Grau' and 'Harbour' channels (Fig. 2A). It is $3.3 \mathrm{~km}$ long $\times 0.8 \mathrm{~km}$ wide, with mean and maximum depths of 0.8 and $2 \mathrm{~m}$, respectively.

The bivalve farm is located in the deeper part $(2 \mathrm{~m})$ of the lagoon near the Grau Channel (Fig. 2B). The lagoon has been exploited for bivalve culture since 1994 . Farmed bivalves include Pacific oysters Crassostrea gigas and Mediterranean mussels Mytilus galloprovincialis. Groups of 3 oysters are glued at intervals along ropes ('sticking') and mussels placed into 2 to 3 biodegradable mesh socks around ropes ('socking') to allow the latter to attach to ropes by byssal threads. Oyster and mussel ropes were suspended from 12 tables $(10 \times 50 \mathrm{~m}$; Fig. 2B), with oysters in the northern part of the farm and mussels in the southern part (Fig. 2B). Tables were protected by a single large net during 2017 and by several smaller (table-scale) nets in 2018 to limit seabream predation. Oyster and mussel production were managed by 2 farmers.

A)

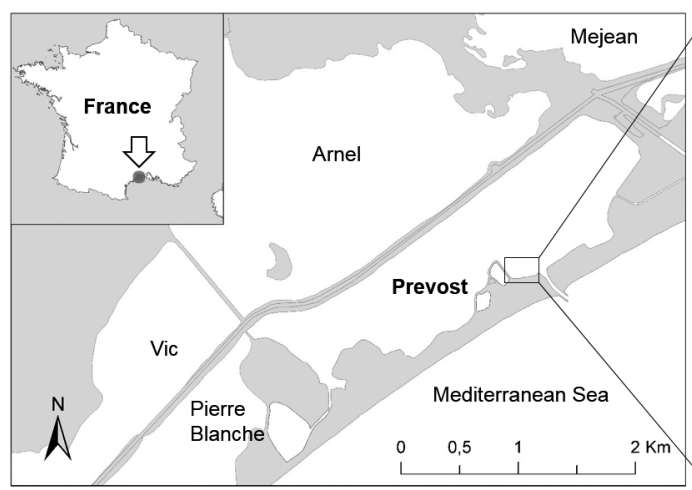

\subsection{Experimental design, sampling, and analyses}

\subsubsection{Temporal observation of tagged gilthead seabream}

A total of 56 seabream were captured in Prevost Lagoon using traditional net fish traps called 'Capechades' or 'Casiers' in the shallower parts of the lagoon ( $\mathrm{n}=49$ ) and by angling inside the farm $(\mathrm{n}=7)$ from May to September 2017. Following capture, seabream were transported to shore and anaesthetized using benzocaine (360 ppm) prior to recording biometric measures (weight [g], total length [TL, mm]). Individual fish TL ranged from 200 to $499 \mathrm{~mm}$ (mean \pm SD: $260 \pm$ $62 \mathrm{~mm}$ ) and weight ranged between 100 and $1729 \mathrm{~g}$ (mean \pm SD: $287 \pm 300 \mathrm{~g}$ ). We defined 2 size classes: small, $\leq 280 \mathrm{~mm}$ TL $(\mathrm{n}=46)$ and large, $\geq 281 \mathrm{~mm}$ TL $(\mathrm{n}=$ 10; see Table 1). Only fish displaying no physical injury or bleeding were tagged. An acoustic tag (VEMCO V9; 180 s nominal delay, 69 kHz, 1 H; estimated tag lifetime 579 d) was surgically implanted into the peritoneal cavity of each fish. An external plastic dart tag was then implanted through the dorsal musculature and a blue tattoo (Cyan natural pigment) applied to each individual. Our experimental procedures, including the use of benzocaine, was validated by our local animal welfare representatives and by the French Ministry of High Education and Research (respectively, APAFIS\#8945-2017021612469374 v4 and C3421926). Tagged individuals were then placed in an observation tank where they were allowed to recover for approximately $1 \mathrm{~h}$ prior to being released back in the farm area. Data from a VR2W (VEMCO, Innovasea) acoustic receiver positioned in the southwest part of the farm (Fig. 2B) was used to assess the presence of tagged individuals in the farm area. This acoustic

B)

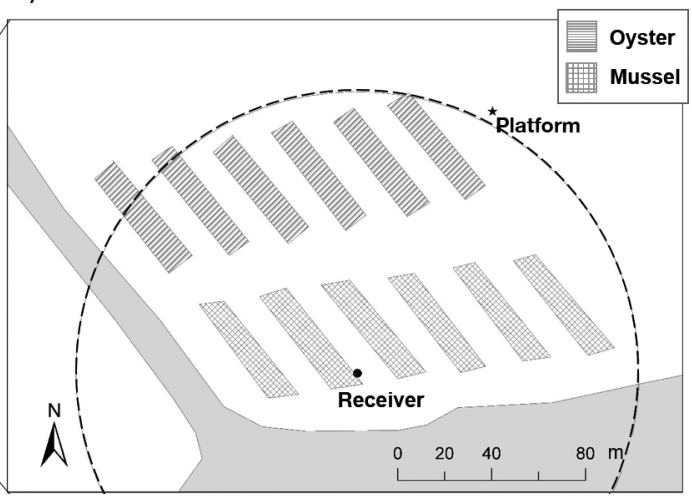

Fig. 2. (A) Prevost Lagoon, southern France, and (B) the bivalve farm comprising 12 tables: 6 of mussels and 6 of oysters, one of which (stocking bag) held market-ready oysters rather than grow-out ropes. Black dot and star: position of the acoustic receiver and experimental platform, respectively; circle: $50 \%$ acoustic detection area. The acoustic receiver and experimental platform were separated by $130 \mathrm{~m}$ 
receiver was part of a larger network of 21 receivers covering the entire lagoon. Two directional receivers were positioned in the Grau channel to detect movements of tagged fish between Prevost Lagoon and the Mediterranean Sea (Fig. 2B). In this study, only data from the receiver positioned in the farm where the experiment took place were used. Because of potential shadowing due to bivalve stock and nets, as observed for fish cages (Otterå \& Skilbrei 2016), a series of range tests were carried out in March 2017, prior to the study. Similar to How \& de Lestang (2012), we estimated acoustic range reception with receivers placed at $37,53,86,122,153,203,254$, and $308 \mathrm{~m}$ from the transmitter. The receivers were deployed along a north-east bearing from the transmitter and across the bivalve farm. Results showed a $50 \%$ detection efficiency at $120 \mathrm{~m}$ (Fig. S1 in the Supplement at www.int-res.com/articles/suppl/q012p529_supp.pdf), thus covering the entire bivalve farm (Fig. 2B).

Data was downloaded from the acoustic receiver at the end of October 2018. Data integrated date, time, and seabream tag ID for each detection. The number of detections for each seabream and number of seabream detected in the bivalve farm were first aggregated by fish size class per day. Data were aggregated by $2.75 \mathrm{~d}$ predation trials (hereafter, 'losses at the unprotected experimental platform') and summed to compare the total number of detections and fish recorded by the acoustic receiver during the duration of each predation trial over the 18 mo study.

\subsubsection{Temporal observation of bivalve losses due to predation}

Bivalve losses due to predation were estimated in the farm and at an unprotected platform.

Field sampling: bivalve stocks and losses in the farm. To estimate bivalve losses due to predation in the farm, it was necessary to first quantify mussel and oyster stocks throughout the 18 mo study period. We thus surveyed the farmers monthly to document oyster and mussel production dynamics at the farmscale. The Prevost Lagoon farmer produced a monthly overview of his 12 tables, detailing stocking dates and the number of ropes that were suspended from each table. Throughout the study period, the table in the northeast corner of the farm (Fig. 2B: 'stocking bag') was used to stock oysters in bags following harvesting from ropes and prior to being sold to market. The other tables had various quantities of oyster and mussel ropes, which were vulnerable to predation. Evaluation of bivalve stocks thus focused on these 11 tables. At the farm-scale, several cohorts of bivalves were raised simultaneously: small (spat and seed), medium (growing bivalves), and large (market-sized bivalves) individuals (Fig. 3). Usually, a single cohort was raised per table and several tables with the same cohort may have been in the farm at any time, as detailed in the farm production plan. Based on this plan, 3 ropes per species and cohort were sampled each month (Fig. 3) for a total of 18 ropes. Each rope was measured and weighed to provide estimates of bivalve stocks per table (estimated as the number of ropes for a given species and cohort multiplied by the relevant mean total rope weight). Weight and size at seeding and harvesting were estimated by sampling individual ropes (samples from the top, middle, and bottom of ropes; Fig. 3).

Field sampling provided a more quantitative understanding of the oyster and mussel production cycles at the farm. Oyster rearing was done in 3 steps: sticking, grow-out, and harvesting. Sixteen lots of 3 oyster juveniles from other production basins were glued with cement on $158 \mathrm{~cm}$ long ropes (sticking; Fig. 3). At sticking, mean $( \pm \mathrm{SD})$ oyster size was $51 \pm 13 \mathrm{~mm}$ and $12.4 \pm 7 \mathrm{~g}$. Oyster sticking was done during 7 periods, including April, May, June, and September 2017, and January, February, and June 2018. Grow-out varied from 5 to 8 mo. At harvest, oysters had reached a mean size of $81 \pm 11 \mathrm{~mm}$ and $53.7 \pm$ $15.2 \mathrm{~g}$. Farm-wide, oyster stocks varied from 5.5 to $34.1 \mathrm{t}$ over the study period.

The production cycle for mussels was 18 mo. Mussel seed was collected from ropes in September, where mussels had settled during March. Seed was placed in biodegradable nets that were wrapped around $116 \mathrm{~cm}$ long ropes (Fig. 3). Mussel ropes were manipulated several times during the production cycle to sort mussels by size before roping them a second and third time. This 'thinning out' was done to increase mussel growth by limiting trophic and spatial competition and mussel fall-off. Five cohorts were followed during the study period. Minimum (maximum) mussel length and weight were $23 \mathrm{~mm}$, $1.1 \mathrm{~g}(73 \mathrm{~mm}, 34 \mathrm{~g})$. At seeding, mean mussel size was $38 \pm 8 \mathrm{~mm}, 6 \pm 3 \mathrm{~g}$. At harvest, mean mussel size was $58 \pm 7 \mathrm{~mm}, 17 \pm 6 \mathrm{~g}$. Farm-wide mussel stocks varied from 14.9 to $26.7 \mathrm{t}$ during the study period.

Each month, bivalve losses (\%) due to predation were estimated visually by the farmers for each table. Losses from the 18 sampled ropes were also estimated quantitatively by Ifremer scientists (Fig. 3). The ropes were carefully examined and photographed. The number of dead organisms and broken shells were re- 


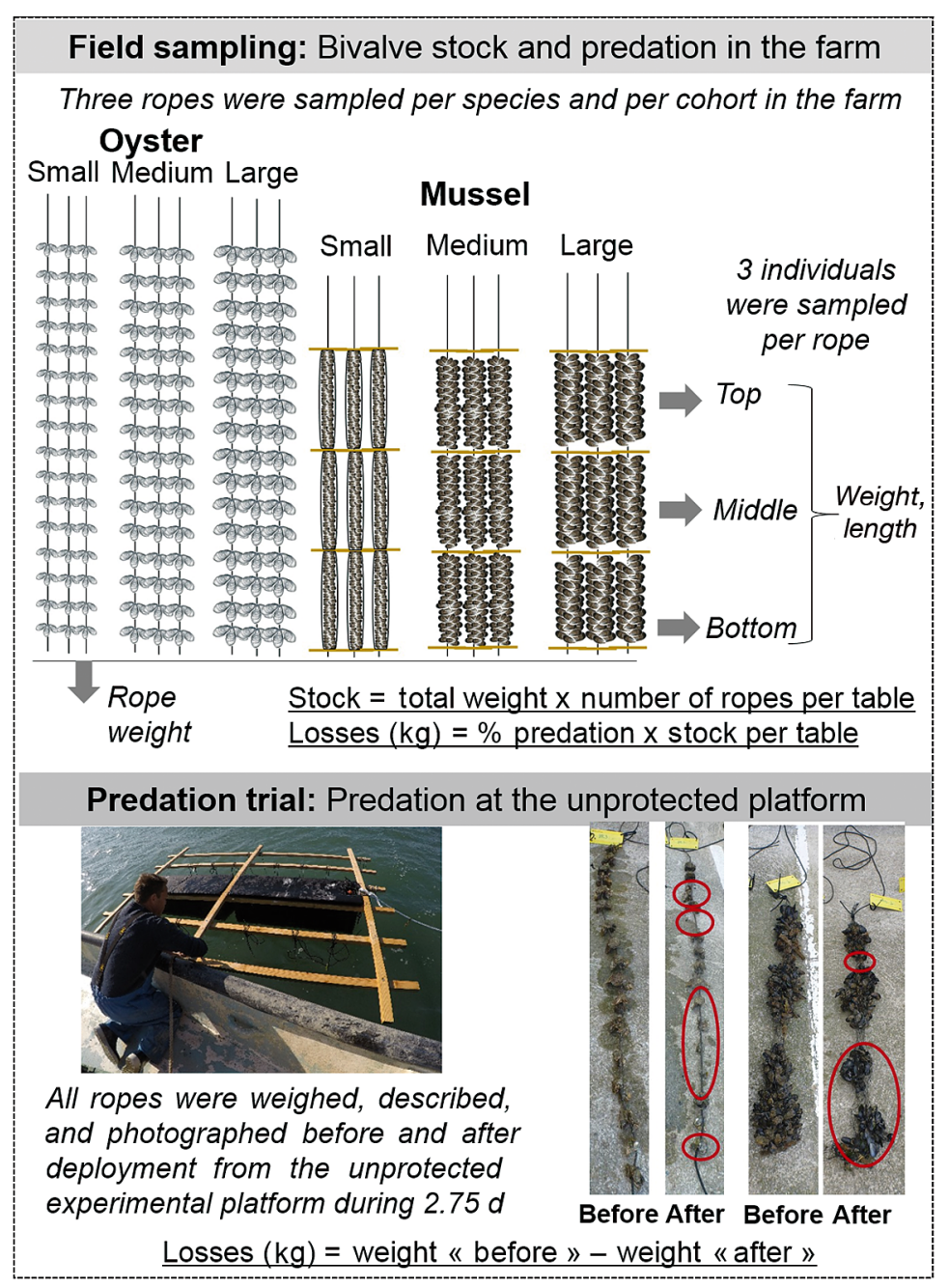

Monthly sampling from April 2017 at October 2018

Fig. 3. Sampling design for field observations and predation trials to determine monthly bivalve stocks and losses in the farm and at the unprotected platform between April 2017 and October 2018

ported by cohort and species. Oyster predation was estimated as the number of oysters lost relative to the number initially cemented on ropes. Mussel losses could not be estimated in the farm by scientists given the great temporal and spatial variation in stocking densities. Finally, bivalve losses were compared to quantities sold, using data provided by the farmers.

Predation trials: bivalve losses at the unprotected experimental platform. Each month, the 18 sampled ropes (Fig. 3) were suspended from an experimental platform that was not protected by nets, located ca. 15 $\mathrm{m}$ east of the farm and ca. $130 \mathrm{~m}$ from the acoustic receiver (Figs. 2B \& 3). Ropes were deployed from Tuesday 14:00 h through Friday 08:00 h (2.75 d). Prior to and following deployments, ropes were weighed, photographed, and described (number of dead, broken shells, and empty segments on ropes). Bivalve losses at the experimental platform were calculated as the difference between initial and final total rope weights post-deployment and expressed as \%. Video recordings and field observations were used to associate estimated losses with signs of predation, i.e. broken shells or detached oysters.

\subsection{Statistical analyses}

Data analyses were performed with $\mathrm{JMP}^{\circledR}$ v.12.0.1 (SAS Institute). Length and weight of tagged seabream detected by acoustic receivers in the farm area were compared to those that were tagged but not detected within the farm area, using the Wilcoxon test. Given that the bivalve loss data did not respect the assumption of normality or homoscedasticity, bivalve losses by sampling date were similarly compared using Wilcoxon tests with species and date as main fixed factors. Likewise, Wilcoxon tests were also used to compare the number of detections per seabream, total number of detections, and number of detected seabream, by date of predation trial and size class. The relationship between mussel losses and the number of seabream detected during predation trials was evaluated using Pearson correlation tests. Results were considered significant at $\mathrm{p}<0.05$.

\section{RESULTS}

\subsection{Temporal observation of tagged gilthead seabream}

\subsubsection{Detections in the farm}

About half $(48 \% ; 27$ of 56$)$ of the tagged seabream were detected by the acoustic receiver in the bivalve farm over the study period. Mean TL and weight of seabream detected in the farm were significantly greater than those that were tagged but not detected 
in the farm (Fig. 4). Most $(90 \% ; \mathrm{n}=9$ ) large tagged seabream were detected in the farm whereas only $33 \%(\mathrm{n}=15)$ of the small tagged seabream were (Table 1). Large seabream were also more frequently detected in the farm than were small ones (Fig. 5), of which 12 were detected less than 5 times over 18 mo (Fig. 5). Of the 9 large seabream detected in the farm, 7 individuals were detected over extended periods $(190 \pm 17 \mathrm{~d})$ and are hereafter referred to as 'residents'. It is of note that 6 of these were initially captured by angling inside the farm (Fig. 5). The acoustic receiver detected between 1 and 9 individuals daily during the detection periods (Fig. 5). No fish were detected in the farm during a nearly 6 mo period, from 7 October 2017 to 31 March 2018. In April 2018, 88 \% (8 of 9) of the large seabream detected in 2017 returned to the farm (Fig. 5, Table 1) whereas only 13\% (2 of 15) of the small seabream detected in $2017 \mathrm{did}_{\text {; }}$ a further 3 small seabream that were not detected in 2017 were also detected in 2018 (Fig. 5).

\subsubsection{Detection during predation trials}

A total of 12 seabream were detected by the acoustic receiver during the predation tests from June to October 2017 and from April to September 2018 (Fig. 6). The number of seabream detected in a given period varied from 2 to 8 , while the total number of detections per day ranged from 2 to 1600 , with a greater number of detections of large than of small seabream (Fig. 6). Indeed, 9 of 12 seabream detected were larger than $281 \mathrm{~mm}$ TL. The greatest number of individuals was detected in October 2017 and May 2018, whereas the greatest total number of detections was recorded in April 2018 and September 2018, respectively. No seabream were detected by the acoustic receiver from November 2017 to March 2018 (Fig. 6). However, several large seabream were fished in the lagoon by a fisherman in November 2017 (see Fig. 9A). Few predators (a single crab was observed in February 2018) were identified by a video camera positioned at the top of ropes.

\subsection{Temporal bivalve losses}

\subsubsection{Bivalve losses in the farm}

Both farmers and and scientists noted high oyster losses following oyster sticking (May to June 2017 and May to July 2018) (Figs. 7A \& 8). Oyster losses ascribed to predation varied from 6 to $100 \%$ during
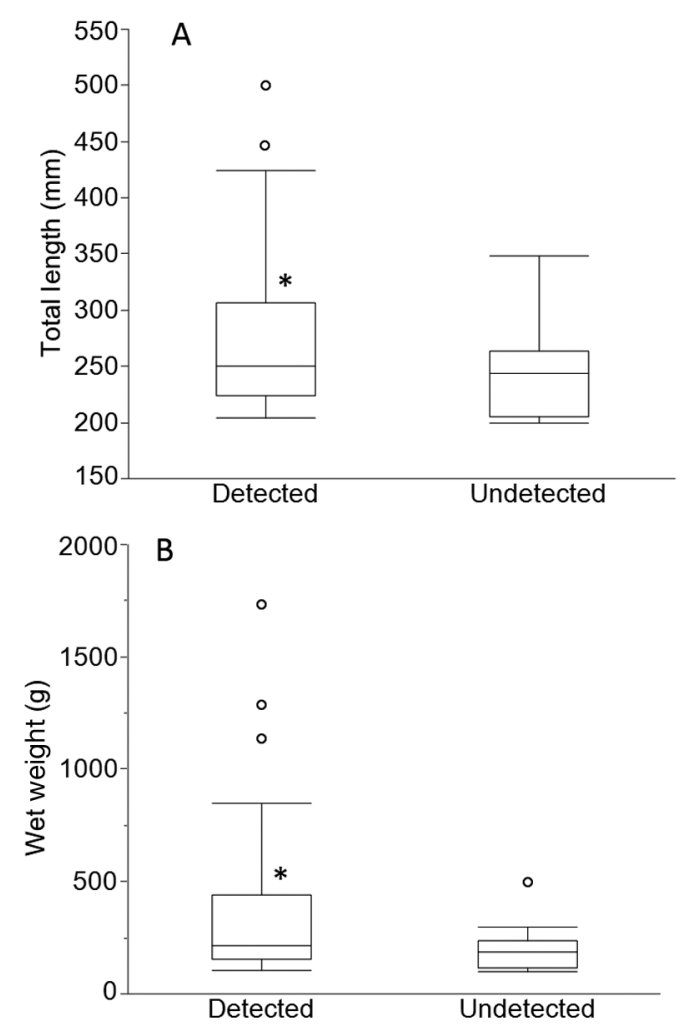

Fig. 4. (A) Total length and (B) wet weight of acoustically detected and non-detected tagged seabream between May 2017 and October 2018. Box plots parameters: line through the box: median; lower and upper boundaries: $25^{\text {th }}$ and the $75^{\text {th }}$ percentiles. The middle half of the data is within the box; the majority of the data falls between the ends of the whiskers. Data points outside the whiskers: potential outliers. Asterisk: significant difference between means (Wilcoxon-Mann-Whitney test, $\mathrm{p}<0.05$ )

Table 1. Mean $( \pm \mathrm{SD}$, range) length, weight, number of initially tagged seabream, and number of seabream detected by the acoustic receiver located in the bivalve farm in 2017 and 2018 by size classes

\begin{tabular}{|c|c|c|c|c|c|}
\hline \multirow{2}{*}{$\begin{array}{l}\text { Size class } \\
(\mathrm{TL}, \mathrm{mm})\end{array}$} & \multirow{2}{*}{$\begin{array}{l}\text { Total length } \\
\quad(\mathrm{mm})\end{array}$} & \multirow{2}{*}{$\begin{array}{l}\text { Weight } \\
\text { (g) }\end{array}$} & \multirow{2}{*}{ Tagged } & \multicolumn{2}{|c|}{ - Detected - } \\
\hline & & & & 2017 & 2018 \\
\hline$\leq 280$ & $\begin{array}{c}237 \pm 26 \\
(200-280)\end{array}$ & $\begin{array}{c}181 \pm 58 \\
(100-298)\end{array}$ & 46 & $15(33 \%)$ & 5 \\
\hline$\geq 281$ & $\begin{array}{c}364 \pm 73 \\
(281-499)\end{array}$ & $\begin{array}{c}771 \pm 46 \\
(420-1729)\end{array}$ & 10 & $9(90 \%)$ & 8 \\
\hline
\end{tabular}

the study period. Massive mussel losses (90\%) were observed after socking (September 2017) (Figs. 7A $\&$ 8). The farmers also reported predation of settled mussels on the metallic structures of the unprotected table for market-ready oysters and mussels (Fig. 2B) from June to September 2017 and April to August 2018 (Fig. 7A). No massive predation was reported 


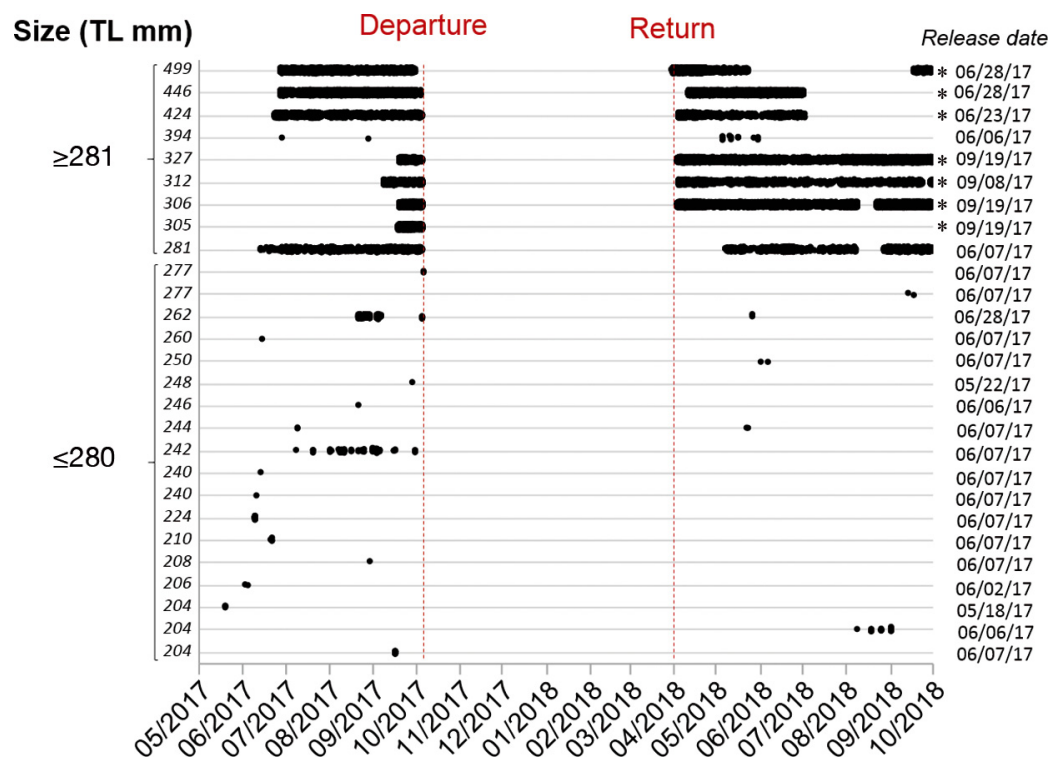

Fig. 5. Daily size-specific seabream detections recorded by the acoustic receiver in the bivalve farm (divided into 2 size categories: $\leq 280$ and $\geq 281 \mathrm{~mm}$ TL), from 20 May 2017 to 30 October 2018. Asterisks indicate that seabream were captured by angling inside the farm; other seabream were captured by traps in shallower parts of the lagoon

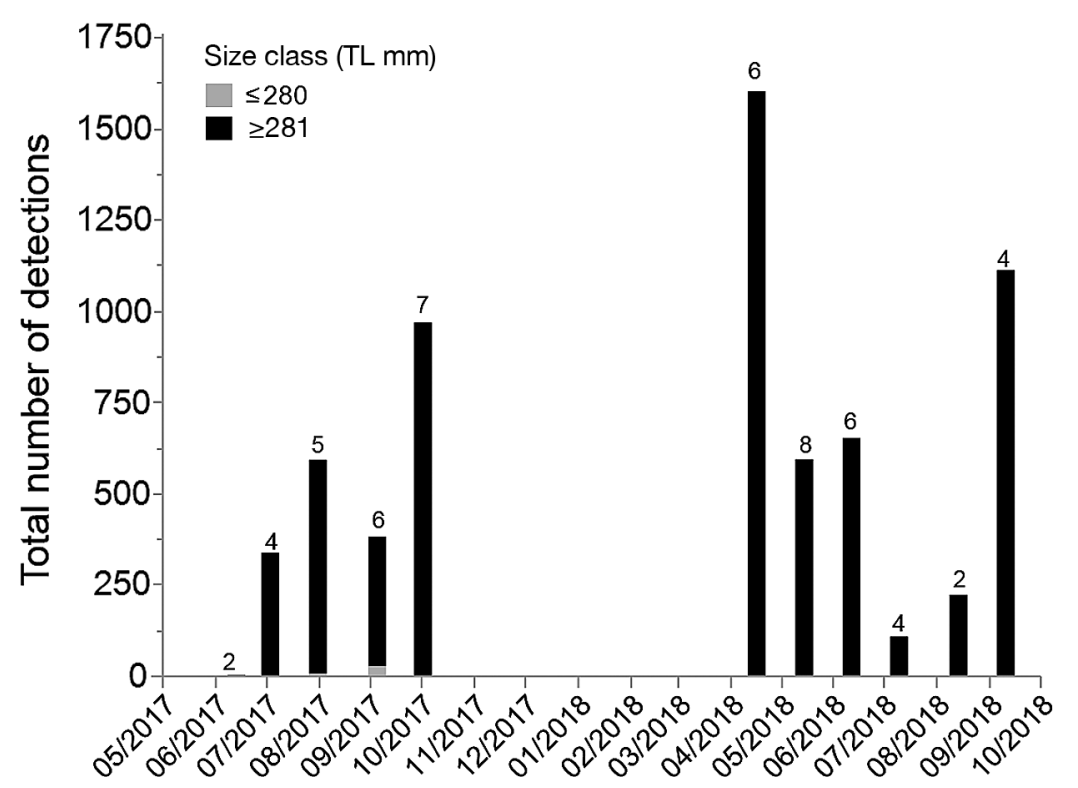

Fig. 6. Total number of seabream detections and number of seabream (number above the bar) recorded by the acoustic receiver by size class ( $\leq 280$ and $\geq 281 \mathrm{~mm}$ TL) during monthly predation tests at the experimental platform (May 2017 to October 2018)

for bivalve ropes on tables that were protected by nets outside of the sticking and roping period (Fig. 7A). Mussel losses attributed to predation varied from 65 to $267 \mathrm{~kg} \mathrm{table}^{-1} \mathrm{mo}^{-1}$ (August to September 2017) during periods of mussel socking compared to a mean of 610 (June 2017) and 2524 (July 2018) kg table ${ }^{-1}$ for newly attached oysters. Over the 18 mo study, total estimated losses were $332 \mathrm{~kg}$ of mussels and $6268 \mathrm{~kg}$ of oysters, representing 1.3 and $27.7 \%$ of the weight of sold mussels (24.8 t) and oysters $(22.6 \mathrm{t})$, respectively.

\subsubsection{Losses at the unprotected experimental platform}

Signs of predation were observed on 48 and $71.4 \%$ of oyster and mussel ropes, respectively, suspended at the unprotected experimental platform throughout the study period. Losses associated with signs of predation varied significantly by species and month. Mean $( \pm \mathrm{SD})$ losses were $11.5 \pm 14.6 \%$ for mussels and $4.1 \pm 4.3 \%$ for oysters. High variability of mussel losses was observed among months and ropes, with losses up to $68 \%$ of the initial weight (Fig. 7B). Mussel losses were generally greatest at the middle and bottom of ropes. Interestingly, bivalve losses and signs of predation (broken shells, detached oysters) were observed throughout the study period (Fig. 7B), even during autumn (November 2017) and winter (January to March 2018) for mussels and oysters (Fig. 9), when no tagged seabream were detected by the acoustic receiver (Fig. 6). No significant correlation was thus observed between bivalve losses (\% or $\mathrm{kg}$ ) and seabream detections (number of individuals or total number of detections) in a given period.

\section{DISCUSSION}

Bivalve predation by seabream has been observed around the world (Brehmer et al. 2003, Saito et al. 2008, Peteiro et al. 2010, Šegvić-Bubić et al. 2011). In southern France, farmed mussel and oyster loss due to seabream predation is a major issue for bivalve farmers. This study is the first assessment of the interactions between gilthead seabream Sparus aurata and farmed bivalves in a French Mediterranean lagoon. 


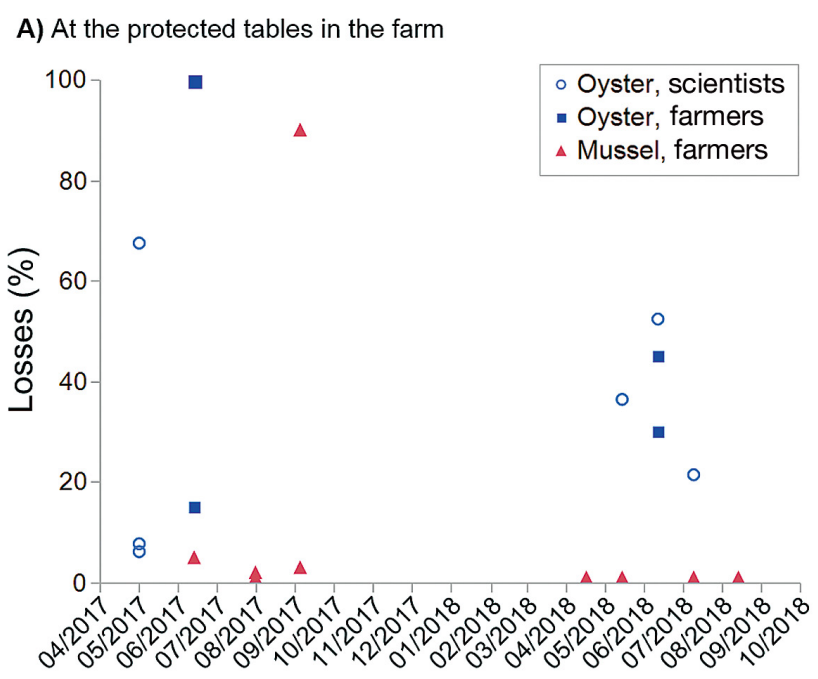

B) At the unprotected experimental platform

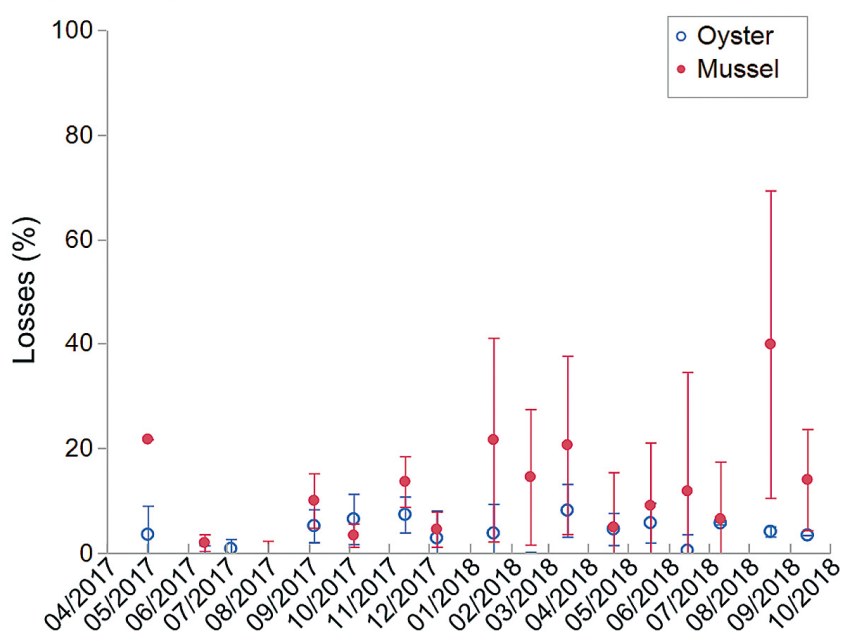

Fig. 7. (A) Estimated mussel and oyster losses recorded by farmers and scientists at the protected tables in the bivalve farm and (B) mean $( \pm \mathrm{SD})$ bivalve losses associated with signs of predation (broken shells or detached oysters) for mussel and oyster ropes suspended at the unprotected experimental platform from May 2017 to September 2018. When no predation was detected, no data was reported in the figure

\subsection{Temporal observation of tagged gilthead seabream in the bivalve farm}

The presence of seabream at the bivalve farm in Prevost Lagoon, as previously inferred by farmers, was confirmed by fishing efforts and acoustic telemetry. About half of the tagged seabream $(48 \% ; 27$ ind.) were detected at least once by the acoustic receiver in the farm area and $26 \%$ of them ( 7 ind.) were detected over an extended period of time $(190 \pm 17 \mathrm{~d})$ in the farm area. Six of these more 'resident' seabream were initially captured inside the farm, whereas most other seabream were captured in the shallower part of the lagoon outside of the farm area. This confirms that bivalve farms provide suitable habitat for seabream and illustrates their site fidelity over the period they spend in the lagoon. In Hiroshima Bay, 6 tagged seabream Acanthopagrus schlegelii were also observed moving in oyster raft areas (Tsuyuki \& Umino 2017), and most of them (5 of 6) were initially captured inside the farm. Such within-lagoon site fidelity was also observed using acoustic telemetry in Portugal, where 2 of 3 tagged seabream were observed to return to the capture site after being released more than $4 \mathrm{~km}$ away (Abecasis \& Erzini 2008).

As with other Sparidae (e.g. Spondyliosoma cantharus; Perodou \& Nedelec 1980, Veiga et al. 2006), $S$. aurata has a distinct seasonal distribution characterized by migrations to inshore waters during warmer periods. The results of this study corroborated observations of seabream entering French Mediterranean coastal lagoons in the spring (Lasserre \& Labourg 1974) and migrating out to sea in the autumn (Audouin 1962, Lasserre 1976). The observed absence of tagged individuals in the farm site between October and April is likely linked to this seasonal migration, with a near-simultaneous departure of seabream from the farm and the lagoon in October confirmed by the 2 receivers in the channel.

Most (9 of 10) large tagged fish were detected by the acoustic receiver whereas small individuals were much less commonly detected within the farm area and, when they were, seemed to be only passing through. Likewise, seabream farm fidelity was mostly observed for large fish, of which $88 \%$ (8 of 9) returned to the farm area after winter compared to only $13 \%$ (2 of 15) for small fish. This size-related effect may be explained by difference in mouth structure and dentition pattern with seabream age; the anterior elongated teeth of larger individuals (140 and $200 \mathrm{~mm}$ TL) likely allow them to better hold or grasp hard prey (Elgendy et al. 2016), including bivalves, thus accounting for the fish's trophic shift with increasing size (Tancioni et al. 2003). In contrast to smaller seabream, the dentition of larger seabream is probably better adapted to feed on mussels and oysters with their round and flattened posterior teeth able to crush shells, as described in Berkovitz \& Shellis (2017). These results corroborate observations by Šegvić-Bubić et al. (2011), who noted a high abundance of large ( 280 to $480 \mathrm{~mm}, 304$ to $1485 \mathrm{~g}$ ) gilthead seabream in a mussel farm in Marina Bay, central Adriatic Sea. In Hiroshima Bay, resident black seabream observed inside the oyster farm area were also large ( 360 to $440 \mathrm{~mm}$ ) individuals (Tsuyuki \& Umino 2017). 


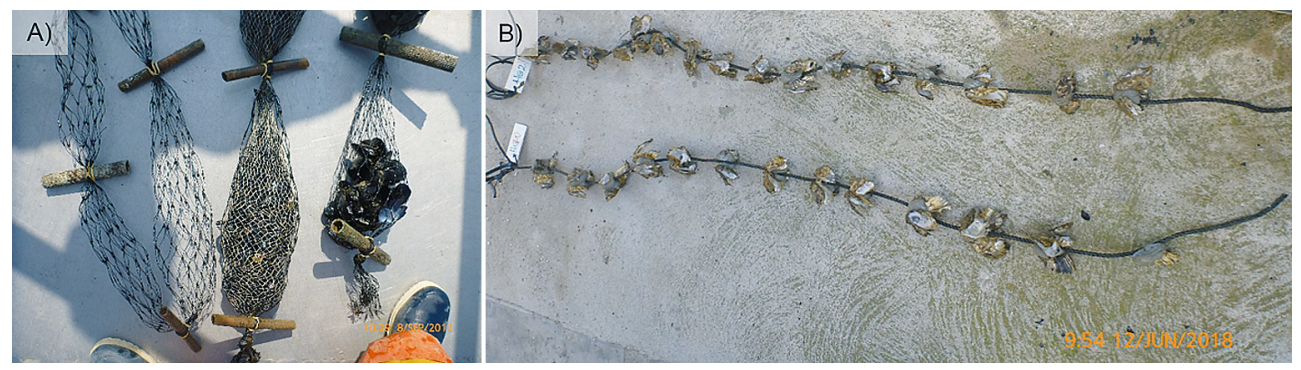

Fig. 8. Evidence of predation on (A) mussels after thinning out and socking (September 2018) and (B) oysters after sticking (June 2018) when seabream were detected by the receiver in the farm

\subsection{Temporal variation in bivalve losses due to seabream predation}

As observed in the Adriatic Sea (Šegvić-Bubić et al. 2011) and Hiroshima Bay (Saito et al. 2008), predation by seabream was observed on both mussels and oysters in the Prevost Lagoon bivalve farm. ŠegvićBubić et al. (2011) observed signs of predation mainly at the bottom of grow-out ropes, as was observed in Prevost Lagoon, with evidence of broken oyster and mussel shells. Mussel ropes were destroyed and the protective socking torn, resulting in mussel ropes with bare patches in extreme cases. Oysters were also detached from cement attachment points on ropes.
Massive predation was observed in the farm from April to September, with losses up to $90-100 \%$, following the deployment of oyster ropes in the farm (sticking) in June and thinning out mussel ropes (socking) in September. Lower losses due to predation were observed for mussels $(11.5 \pm 14.6 \%)$ and oysters $(4.1 \pm 4.3 \%)$ within $2.75 \mathrm{~d}$ at the experimental platform, perhaps reflecting lower attractiveness of bivalves to seabream at the experimental platform rather than following handling in the farm or simply the shorter deployment time. During mussel thinning out and oyster sticking, bivalves were immersed for a minimum of $24 \mathrm{~h}$ on sorting tables before being suspended from farm tables in the lagoon. This handling
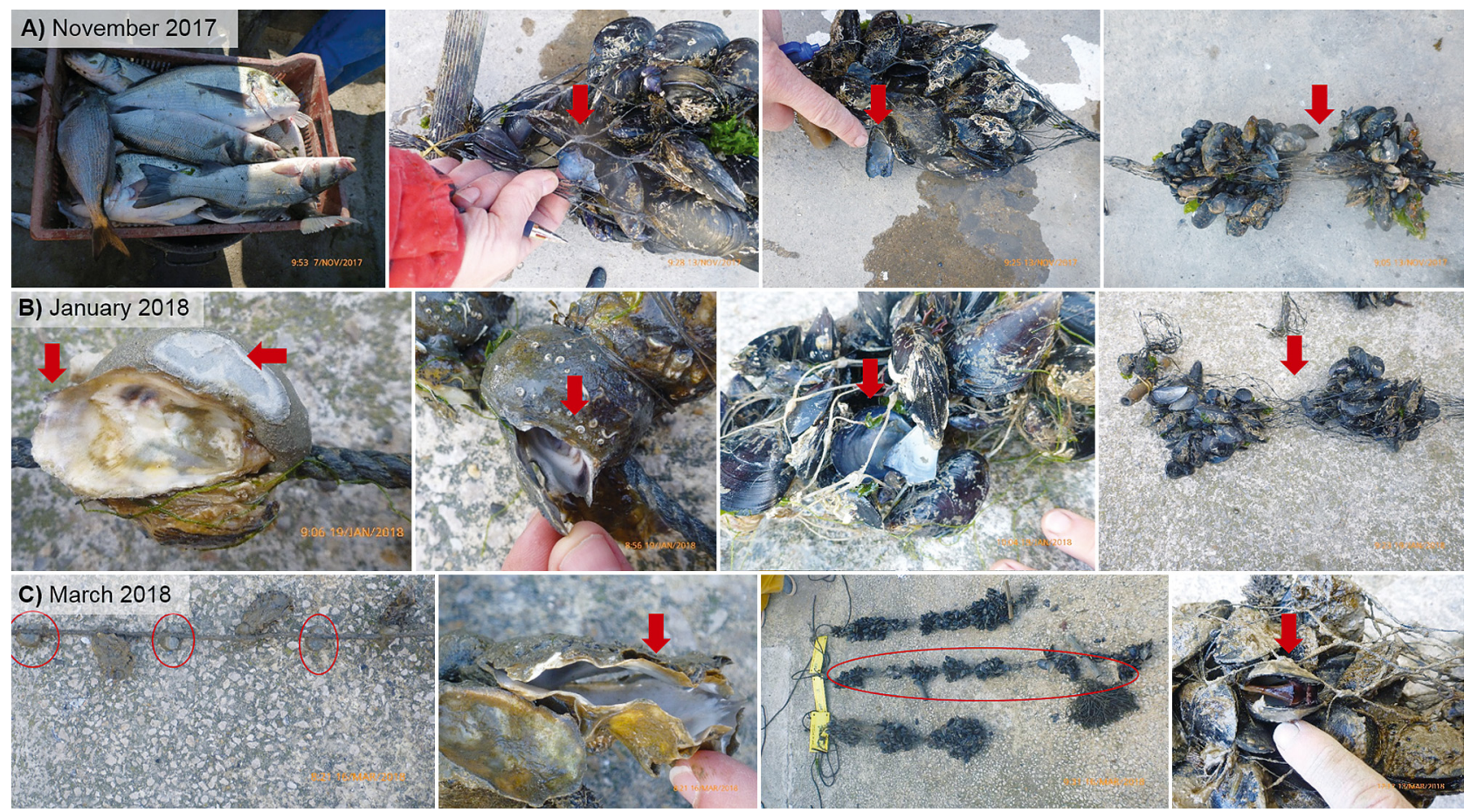

Fig. 9. (A) Large seabream fished in November 2017 and signs of predation on mussel and oyster ropes in November 2017, (B) January 2018, and (C) March 2018 when seabream were not detected by the receiver in the farm. Dates are shown in the lower right corner of each photograph 
may have stressed and weakened the bivalves. Mussels have been shown to be particularly susceptible to predation in the first $24 \mathrm{~h}$ following socking, prior to the animals being firmly attached to grow-out structures and each other by byssal threads (ŠegvićBubić et al. 2011), highlighting the importance of protecting bivalves by nets following socking.

Oysters and mussels without protective nets were predated on throughout the study period. Although high mussel losses have been shown to coincide with the occurrence of large schools of seabream in some areas (Šegvić-Bubić et al. 2011, Fig. 1), bivalve losses in the present study were not correlated with the number of tagged seabream detected during the predation trial periods. Although tagged seabream were not detected by the farm receiver from November to March, signs of predation were observed each month during this period. This may be explained by a number of possible mechanisms. First, detection probability of tagged fish may have decreased in the autumn and winter given generally poorer weather conditions. Indeed, wind and rain have been found to significantly impact detection rates (Gjelland \& Hedger 2013). However, no tagged seabream were detected anywhere in the lagoon during this period by other receivers deployed as part of a larger study on fish movements in this water body. Further, the 2 receivers positioned in the narrow Grau channel (20 $\mathrm{m}$ wide and $180 \mathrm{~m}$ long) detected all tagged seabream leaving the lagoon during October and, although both of these channel receivers detected several tagged seabass Dicentrachus labrax entering and leaving the lagoon through the winter, no tagged seabream were detected at this time. Together, this suggests that tagged seabream were not present nor had they briefly returned to the lagoon over this period.

A second possibility is that mussels and oysters may have been predated by untagged seabream. Although predation pressure on mussels and oysters could come from seabream escapees from on-growing facilities, it is unlikely that this is the case in Prevost Lagoon since the closest growing site is located $170 \mathrm{~km}$

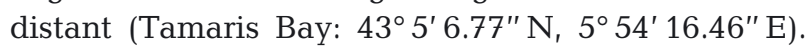
Studies have shown that escapees show a high fidelity to the rearing site during the first $2 \mathrm{wk}$ following escape (Šegvić-Bubić et al. 2018), and disperse within a radius of only a few $\mathrm{km}$ during the first few days ( $<3 \mathrm{~km}$ in $9 \mathrm{~d}$; Arechavala-Lopez et al. 2018) with maximum recorded recapture distances of $20 \mathrm{~km}$ after 1 mo for some surviving individuals (ArechavalaLopez et al. 2012). Furthermore, the seabream farm in Tamaris produces few individuals, at $100 \mathrm{t} \mathrm{yr}^{-1}$. Considering that mortality rates of escapees are often very high (60\%; Arechavala-Lopez et al. 2012), it is unlikely that these seabream would be found in Prevost Lagoon. Fishermen stated that wild and farmed seabream can be easily distinguished by the missing scales of farmed individuals. They reported catching only wild seabream on mussel farms in Tamaris Bay and Prevost Lagoon. As such, we believe that the predation of mussels and oysters observed in the Prevost Lagoon during this period was by wild seabream. This may have been possible, particularly in early November, given that temperatures are mild at that time (Fig. S2), that large seabream were caught in Prevost Lagoon on 7 November 2017 (Fig. 8), and that observations from other Mediterranean lagoons have shown some seabream may be resident in them for $11 \mathrm{mo} \mathrm{yr}^{-1}$, often including winter months (Mercier et al. 2012). Indeed, unusual captures of seabream were recorded in the fall (October, November 2017) and early winter (December 2018) in the Palavas Lagoon complex (i.e. Prevost, Vic, Moures, Arnel, and Pierres blanches lagoons), unlike other recent years (2009 to 2019). However, this was probably not the case in January and February 2018, when no catches were recorded. The temperatures observed during the winter $\left(9.5 \pm 2^{\circ} \mathrm{C}\right.$, median: $10.1^{\circ} \mathrm{C}$, min.: $2.9^{\circ} \mathrm{C}$, max.: $12.2^{\circ} \mathrm{C}$; Fig. S2) were well above the lethal threshold $\left(5^{\circ} \mathrm{C}\right.$ i Barnabé 1990) and below the feeding threshold $\left(13^{\circ} \mathrm{C}_{i}\right.$ Ibarz et al. 2003) for seabream. Temperatures below $12^{\circ} \mathrm{C}$ are considered unsuitable for seabream (Ibarz et al. 2003). However, known physiological constraints suggest that it is unlikely that the mussels and oysters were eaten by untagged seabream during these cold months.

Third, it is conceivable that mussels and oysters in January and February may have been eaten by other predators. It is of note that a large crab was observed by video at the top of a mussel rope in February. It was probably Carcinus aestuarii (=mediterraneus), which is very common on the Mediterranean coast and present in Prevost Lagoon (Mari \& Bonami 1987). Many crabs are known to feed on mussels and are attracted to mussel culture sites (Callier et al. 2018). It is unknown whether other species may have contributed to predation during the winter. European eels Anguila anguila were observed in Prevost Lagoon during this season (Bouchereau et al. 2006). As was observed in Japan with A. japonica on pearl oysters (Bondad-Reantaso et al. 2007), local farmers have reported seeing eels feeding on bivalves. The large white seabream Diplodus sargus may also be responsible for bivalve predation since they are known to eat mollusks and are present in the Lion Gulf and Prevost Lagoon (Rosecchi 1987) and were 
observed during field work on the bivalve farm. Further predation trials could help identify which species feed on bivalves during the winter months. This work could include (1) tagging additional seabream as well as A. Anguilla, D. sargus, and C. aestuarii, (2) deploying further unprotected bivalve ropes in the heart of the bivalve farm, and (3) using autonomous video monitoring of the bottom of bivalve ropes with wide angles to identify potential predators.

Mussel and oyster losses due to predation in the bivalve farm during the 18 mo study period were estimated at 1.3 and $27.7 \%$, respectively, of the biomass sold annually. These losses are of the same order of magnitude as those observed in Thau Lagoon (26\% of mussel production; Gervasoni \& Giffon 2016). Predation losses at the experimental platform reached $68 \%$ of the initial weight of mussel ropes after $2.75 \mathrm{~d}$. These results are similar to those observed by Šegvić-Bubić et al. (2011), who suggest that mussel losses accounted for $54 \%$ of the initial input of mussel seed following the first week postsocking. The present study showed that the use of nets is essential to reduce the risk of predation throughout the year. Nevertheless, the problem with nets is that over time they can sink or tear, allowing fish to enter the farm and feed on bivalves. A collaboration between bivalve farmers and fishermen could be a sustainable solution for bivalve farming, by regularly fishing seabream between tables and within protective nets and thus reducing predation pressure.

\section{CONCLUSIONS}

This study is the first to highlight the presence of seabream in the Prevost Lagoon bivalve farm and suggests a seasonal feeding fidelity by large seabream in the farm. Signs of predation on mussels and oysters (broken shells, detached oysters, patchy ropes) were observed throughout the year at the experimental platform. Massive bivalve losses in the farm from April through September were reported by the farmers, with maximal losses (90 to $100 \%$ ) occurring following oyster sticking and mussel socking in June and September, respectively. Protection of bivalves by efficient nets is fundamental to limit the risk of predation throughout the year. A collaboration between bivalve farmers and fishermen could be a sustainable solution for bivalve farming, by regularly fishing seabream between tables and within protective nets, thus reducing predation pressure.

Video surveillance at the bottom of ropes (e.g. Tonk et al. 2019, Sheehan et al. 2020) and additional tagging of large seabream and other potential predators (Anguila anguila, Diplodus sargus, Carcinus aestuarii) could help identify overwintering predators. Bioacoustic monitoring (Gannon 2008, Picciulin et al. 2016, Colla et al. 2018) could also be used as a complementary tool to assess predation events and intensity with a focus on shell crushing sounds.

Acknowledgements. The authors thank the President (B. Azema) and the Director of the 'CAT de Maguelone' (F. Vabre) who contributed to the success of this study. Thanks to the bivalve farmers (L. Chalton and E. Villemin), the employees of the farm: 'Les compagnons', technicians (G. Devique, N. Guenineche, G. Robinet, B. Brisset), and students (A. Bourgouin, C. Huiban, I. Neveu, L. Wanschoor) for their help in the field. Thanks to M. L. Begout and G. Messiaen for lending us the acoustic receiver and the NKE probe, to E. Rezzouk for welcoming the team at the Ifremer Palavas Station to do biometric work, and to N. Cimiterra for providing maps. Finally, we would like to thank F. Leguen, responsible of the seabream farm (Hydraloup) in the Tamaris Bay for our exchanges about seabream escapees. This study was carried out as part of the Galway project funded by Fisheries and Oceans Canada (DFO) and the SBTag project funded by the Ifremer Scientific Direction (France).

\section{LITERATURE CITED}

Abecasis D, Erzini K (2008) Site fidelity and movements of gilthead sea bream (Sparus aurata) in a coastal lagoon (Ria Formosa, Portugal). Estuar Coast Shelf Sci 79: 758-763

Arechavala-Lopez P, Uglem I, Fernandez-Jover D, BayleSempere JT, Sanchez-Jerez P (2012) Post-escape dispersion of farmed seabream (Sparus aurata L.) and recaptures by local fisheries in the Western Mediterranean Sea. Fish Res 121-122:126-135

Arechavala-Lopez P, Izquierdo-Gomez D, Forcada A, Fernandez-Jover D, Toledo-Guedes K, Valle C, SanchezPerez P (2018) Recapturing fish escapes from coastal farms in the western Mediterranean Sea: insights for potential contingency plans. Ocean Coast Manage 151:69-76

Audouin J (1962) La daurade de l'étang de Thau Chrysophrys aurata (Linné). Rev Trav Inst Peches Marit 26: 105-126

Barnabé G (1990) Rearing bass and gilthead sea bream. In: Barnabé G (ed) Aquaculture. Horwood, London, p 647-686

Berkovitz B, Shellis P (2017) Bony fishes. In: The teeth of nonmammalian vertebrates. Elsevier, Amsterdam, p 43-111

Bondad-Reantaso MG, McGladerry SE, Berthe FCJ (2007) Pearl oyster health management: a manual. FAO, Rome

Bouchereau J, Marques C, Pereira P, Guelorget O, Vergne Y (2006) Trophic characterization of the Prévost Lagoon (Mediterranean Sea) by the feeding habits of the European eel Anguilla anguilla. Cah Biol Mar 47:133-142

* Brehmer P, Gerlotto F, Guillard J, Sanguinède F, Guénnegan Y, Buestel D (2003) New applications of hydroacoustic methods for monitoring shallow water aquatic ecosystems: the case of mussel culture grounds. Aquat Living Resour 16:333-338

* Callier MD, Byron CJ, Bengtson DA, Cranford PJ and others (2018) Attraction and repulsion of mobile wild organisms 
to finfish and shellfish aquaculture: a review. Rev Aquacult 10:924-949

Colla S, Pranovi F, Fiorin R, Malavasi S, Picciulin M (2018) Using passive acoustics to assess habitat selection by the brown meagre Sciaena umbra in a northern Adriatic Sea mussel farm. J Fish Biol 92:1627-1634

Elgendy SAA, Alsafy MAM, Tanekhy M (2016) Morphological characterization of the oral cavity of the gilthead seabream (Sparus aurata) with emphasis on the teethage adaptation. Microsc Res Tech 79:227-236

Escalas A, Ferraton F, Paillon C, Vidy G and others (2015) Spatial variations in dietary organic matter sources modulate the size and condition of fish juveniles in temperate lagoon nursery sites. Estuar Coast Shelf Sci 152:78-90

FAO (2018) The state of world fisheries and aquaculture 2018: meeting the sustainable development goals. FAO, Rome

Gangnery A, Chabirand JM, Lagarde F, Le Gall P, Oheix J, Bacher C, Buestel D (2003) Growth model of the Pacific oyster, Crassostrea gigas, cultured in Thau Lagoon (Méditerranée, France). Aquaculture 215:267-290

Gannon DP (2008) Passive acoustic techniques in fisheries science: a review and prospectus. Trans Am Fish Soc 137:638-656

Gervasoni E, Giffon C (2016) La conchyliculture en Occitanie. Résultats d'une enquête menée auprès de 135 entreprises conchylicoles. Monographie Conchylicole. CEPRALMAR, Sète

* Gjelland KØ, Hedger RD (2013) Environmental influence on transmitter detection probability in biotelemetry: developing a general model of acoustic transmission. Methods Ecol Evol 4:665-674

How RJ, de Lestang S (2012) Acoustic tracking: issues affecting design, analysis and interpretation of data from movement studies. Mar Freshw Res 63:312-324

* Ibarz A, Blasco J, Gallardo MA, Sánchez J (2003) Oxygen consumption and feeding rates of gilthead sea bream (Sparus aurata) reveal lack of acclimation to cold. Fish Physiol Biochem 29:313-321

Isnard E, Tournois J, McKenzie DJ, Ferraton F, Bodin N, Aliaume C, Darnaude AM (2015) Getting a good start in life? A comparative analysis of the quality of lagoons as juvenile habitats for the gilthead seabream Sparus aurata in the Gulf of Lions. Estuaries Coasts 38:1937-1950

Lasserre G (1976) Dynamique des populations ichtyologiques lagunaire-application à Sparus aurata L. PhD thesis, Université des Sciences et Techniques du Languedoc, Montpellier

Lasserre G, Labourg PJ (1974) Étude comparée de la croissance de la daurade Sparüs auratus L. des régions d'Arcachon et de Sète (deuxième note). Vie Milieu 24:357-363

Le Gal F (2017) Bilan de la production conchylicole dans le département de l'Hérault en 2016. Direction Départementale des Territoires et de la Mer-DDTM 34, Sète

Mari J, Bonami JR (1987) A reolike virus of the Mediterranean shore crab Carcinus mediterraneus. Dis Aquat Org 3: 107-112

Mercier L, Mouillot D, Bruguier O, Vigliola L, Darnaude AM (2012) Multi-element otolith fingerprints unravel sealagoon lifetime migrations of gilthead sea bream Sparus aurata. Mar Ecol Prog Ser 444:175-194

* Otterå H, Skilbrei OT (2016) Influence of depth, time and

Editorial responsibility: Pablo Arechavala-Lopez, Esporles, Illes Balears, Spain human activity on detection rate of acoustic tags: a case study on two fish farms. J Fish Biol 88:1229-1235

Perodou JB, Nedelec D (1980) Bilan d'exploitation du stock de dorade grise. Sci Pêche Bull Inst Pêches Mar 308:1-7

* Peteiro LG, Filgueira R, Labarta U, Fernández-Reiriz MJ (2010) The role of fish predation on recruitment of Mytilus galloprovincialis on different artificial mussel collectors. Aquacult Eng 42:25-30

* Picciulin M, Colla S, Pranovi F, Malavasi S, Fiorin R, Bolgan $M$ (2016) The soundscape of a mussel farm: biophony and man-made noise levels. Proc Mtgs Acoust 27:010016

* Pita BC, Gamito S, Erzini K (2002) Feeding habitats of the gilthead seabream (Sparus aurata) from the Ria Formosa (southern Portugal) as compared to the black seabream (Spondyliosama cantharus) and the annular seabream (Diplodus annularis). J Appl Ichthyology 18:81-86

Rosecchi E (1987) The feeding of Diplodus annularis, Diplodus sargus, Diplodus vulgaris and Sparus aurata (Pisces, Sparidae) in the Gulf of Lions and the coastal lagoons. Rev Trav Inst Peches Marit 49:125-141

* Saito H, Nakanishi Y, Shigeta T, Umino T, Kawai K, Imabayashi $H$ (2008) Effect of predation of fishes on oyster spats in Hiroshima Bay. Bull Jpn Soc Sci Fish 74:809-815

Sakai Y, Shimizu N, Umino T (2013) A list of fishes found on the oyster farming rafts by the underwater visual census in northern Hiroshima Bay, Seto Inland Sea, Japan. J Grad Sch Biosph Sci 52:25-33

Šegvić-Bubić T, Grubisic L, Karaman N, Vjekoslav T, Mislov Jelavic K, Katavic I (2011) Damages on mussel farms potentially caused by fish predation - Self service on the ropes? Aquaculture 319:497-504

*Šegvić-Bubić T, Arechavala-Lopez P, Vučić I, Talijančić I, Grubišić L, Žužul I, Kovač Ž (2018) Site fidelity of farmed gilthead seabream Sparus aurata escapees in a coastal environment of the Adriatic Sea. Aquacult Environ Interact 10:21-34

* Sheehan EV, Bridger D, Nancollas SJ, Pittman SJ (2020) PelagiCam: a novel underwater imaging system with computer vision for semi-automated monitoring of mobile marine fauna at offshore structures. Environ Monit Assess 192:11

*Tancioni L, Mariani S, Maccaroni A, Mariani A, Massa F, Scardi M, Cataudella S (2003) Locality-specific variation in the feeding of Sparus aurata L.: evidence from two Mediterranean lagoon systems. Estuar Coast Shelf Sci 57:469-474

Tonk L, Bernard MS, Jansen H (2019) The use of videotechniques for monitoring and quantification of mobile fauna in marine cultivation systems. Wageningen Marine Research Report No. C017/19. Wageningen Marine Research, Yerseke

Tournois J, Ferraton F, Velez L, McKenzie DJ, Aliaume C, Mercier L, Darnaude AM (2013) Temporal stability of otolith elemental fingerprints discriminates among lagoon nursery habitats. Estuar Coast Shelf Sci 131:182-193

* Tsuyuki A, Umino T (2017) Spatial movement of black sea bream Acanthopagrus schlegelii around the oyster farming area in Hiroshima Bay, Japan. Fish Sci 83:235-244

* Veiga P, Vieira L, Bexiga C, Sá R, Erzini K (2006) Structure and temporal variations of fish assemblages of the Castro Marim salt marsh, southern Portugal. Estuar Coast Shelf Sci 70:27-38

Submitted: February 17, 2020; Accepted: October 8, 2020 Proofs received from author(s): November 30, 2020 